\title{
Sustainable development of the agro-industrial complex of Kazakhstan as the basis of the country's food security
}

\author{
O. I. Malyarenko', G. M. Kushebina ${ }^{2 \bowtie}$ \\ ${ }^{1}$ Kostanay Branch of Chelyabinsk State University, Kostanay, Republic of Kazakhstan \\ ${ }^{2}$ Kostanay Engineering and Economic University named after. M. Dulatov, Kostanay, \\ Republic of Kazakhstan \\ E-mail:duz_77@mail.ru
}

Abstract. The purpose. Assessment of the current state of the agro-industrial complex of Kazakhstan, its role in ensuring the country's food security, substantiation of the directions of its development and minimization of threats to food security. Methods. In the course of the study, analytical and economic-statistical methods, general scientific methods of systemic, comparative and structural-logical analysis were used. Results. The article presents the results of an assessment of the current state of agriculture in the Republic of Kazakhstan and the main criteria for the country's food security: dynamics and volume of sown areas, livestock and poultry, crop yields, dynamics of crop and livestock production, volumes and dynamics of imports and exports of food products, the level depreciation of fixed assets and provision of agricultural producers with machinery. The main problems of agricultural production are identified, the threats to the country's food security are identified. Measures of state support and state regulation of the agro-industrial complex of the country aimed at its further development, increasing the efficiency of its activities, increasing the competitiveness of domestic products in the domestic and foreign markets, saturating the domestic market with socially significant food products in order to ensure the country's food security are disclosed. The trends in the development of the agro-industrial complex within the framework of the main state development programs are given: Concepts for the development of the agro-industrial complex of Kazakhstan for 2021-2030 and the National project for the development of the agro-industrial complex for 2021-2025. Scientific novelty lies in the study of the problems of the country's food security and the sustainable development of the agro-industrial complex, and the determination of the main directions for the development and state support of agricultural production in order to increase the level of the country's food security.

Keywords: food security, food security indicators, food import and export, government support, subsidies, depreciation of fixed assets, government development programs, agricultural production, food security threats, development directions.

For citation: Malyarenko O. I., Kushebina G. M. Sustainable development of the agro-industrial complex of Kazakhstan as the basis of the country's food security // Agrarian Bulletin of the Urals. 2022. No. 01 (216). Pp. 86-91. DOI: 10.32417/1997-4868-2022-216-01-86-91.

Date of paper submission: 29.11.2021, date of review: 07.12.2021, date of acceptance: 13.12.2021.

Introduction

Today, the agro-industrial complex of Kazakhstan is one of the important sectors of the economy, which forms the food and economic security of the country, as well as the labor potential of those employed in agricultural production. Food security is the degree to which the population of the country is provided with environmentally friendly and healthy food products of domestic production at scientifically based standards and affordable prices $[1, \mathrm{p} .63]$.

The problem of ensuring the country's food security is a strategic one, since food security is the basis of the national security of the state. Fundamental issues of food security and reducing the risks of future food shortages constitute a critical function of the agricultural sector of the economy. In this regard, there is a need for a new, verified approach to the sustainable development of the 86 agricultural sector, creating conditions for the processing of raw materials within the country, attracting investments and the latest agricultural technologies, ensuring the stability of state support measures, and increasing their effectiveness [2].

That is why the issues of food independence of Kazakhstan, providing the country's population with highquality food, the need for state support for agricultural producers acquire national economic significance, which determines the relevance of the research topic.

The purpose of the study is to analyze the current state of agricultural production in Kazakhstan, indicators of its food security, identify the main problems in the development of the agricultural sector and threats to food security, determine priority areas for the development and state support of the country's agro-industrial complex. 
Agrarian Bulletin of the Urals No. 01 (216), 2022

Recently, scientific research in the field of ensuring the country's food security, the relevance of state support and regulation of agricultural producers are reflected in the works of: N. I. Shagaida [1], L. P. Goncharenko [3], S. V. Dokholyan [4], I. P. Chupina [14], Sh. K. Nurbekova, M. A. Akhmedieva [5], G. M. Dyuzelbaeva, O. I. Malyarenko [10], L. A. Kopteva [16].

The literature review revealed the importance of continuing research in this area and studying a wide range of issues related to food security and sustainable development of the country's agro-industrial complex.

\section{Methods}

In the course of the study, analytical and economicstatistical methods, general scientific methods of systemic, comparative and structural-logical analysis were used.

\section{Results}

Ensuring the food security of the country depends on two main aspects:

1) the level of development of agricultural production, which allows satisfying the demand for food products in the amount of at least $80 \%$ of the needs of the domestic market, i.e. food independence;

2) the level of purchasing power of the population in the amounts determined by the executive authorities as a living wage, i.e. accessibility for every citizen of the country of food [3, p. 163].

The state and sustainable development of the country's agriculture has a direct and immediate impact on food security. The degree of ensuring the food security of the state depends, first of all, on the "basic potential of agricultural production" [4, p. 1878].

To assess the level of food security, the system of the following indicators is used (Fig. 1).

Thus, for Kazakhstan, the optimal approach to solving the problem of food security should be considered self-sufficiency in products, that is, the sustainable development of the agricultural sector. Today, the agricultural production of Kazakhstan has all the opportunities and conditions to fully meet the needs of the domestic market with agricultural products, and the necessary production volumes for its export.
Consider the main indicators characterizing the state of agriculture in Kazakhstan (table 1).

Over the past three years, agricultural production in Kazakhstan has shown a steady growth trend. Agriculture creates about $5 \%$ of the country's gross domestic product. In 2020, the gross agricultural output amounted to 6.3 trillion tenge, which is higher than the level of 2018 by $41.5 \%$, in real terms by $2 \%$. Gross crop production for the study period shows an increase of $53 \%$, livestock production $28.6 \%$, sown areas for the study period increased by $4.8 \%$ and amounted to 15878.4 thousand hectares at the end of 2020. The structure of sown areas for 2018-2020 remains practically unchanged, on average $75 \%$ is occupied by grain crops, however, the diversification of the structure of sown areas continues, the crops of vegetables, oilseeds, and fodder crops are increasing. The yield of grain and leguminous crops shows a downward trend in 2020 by $5 \%$, however, compared to 2019 , it is growing, the average yield for the analyzed period was $12.6 \mathrm{c} / \mathrm{ha}$, yield fluctuations are insignificant, which indicates the stability of the country's grain production.

Livestock production for the study period mainly shows a growth trend - the number of cattle increased by $9.7 \%$, milk production by 365.2 thousand tons, meat production by 109.2 thousand tons. In 2020 , there was a decrease in the number of poultry by $2 \%$ compared to 2019, due to an outbreak of bird flu, however, the state took measures to support and restore the number of birds in personal subsidiary farms and poultry farms and compensated damage to individuals and legal entities in the amount of 3, 0 billion tenge.

In general, the profitability of agricultural production in Kazakhstan increased by $4.3 \%$ over the period 2018-2020, while labor productivity increased by $11 \%$ over the period under study. It can be noted that over the past few years, thanks to increased attention to agricultural producers by the state, it was possible to stabilize the situation in the industry.

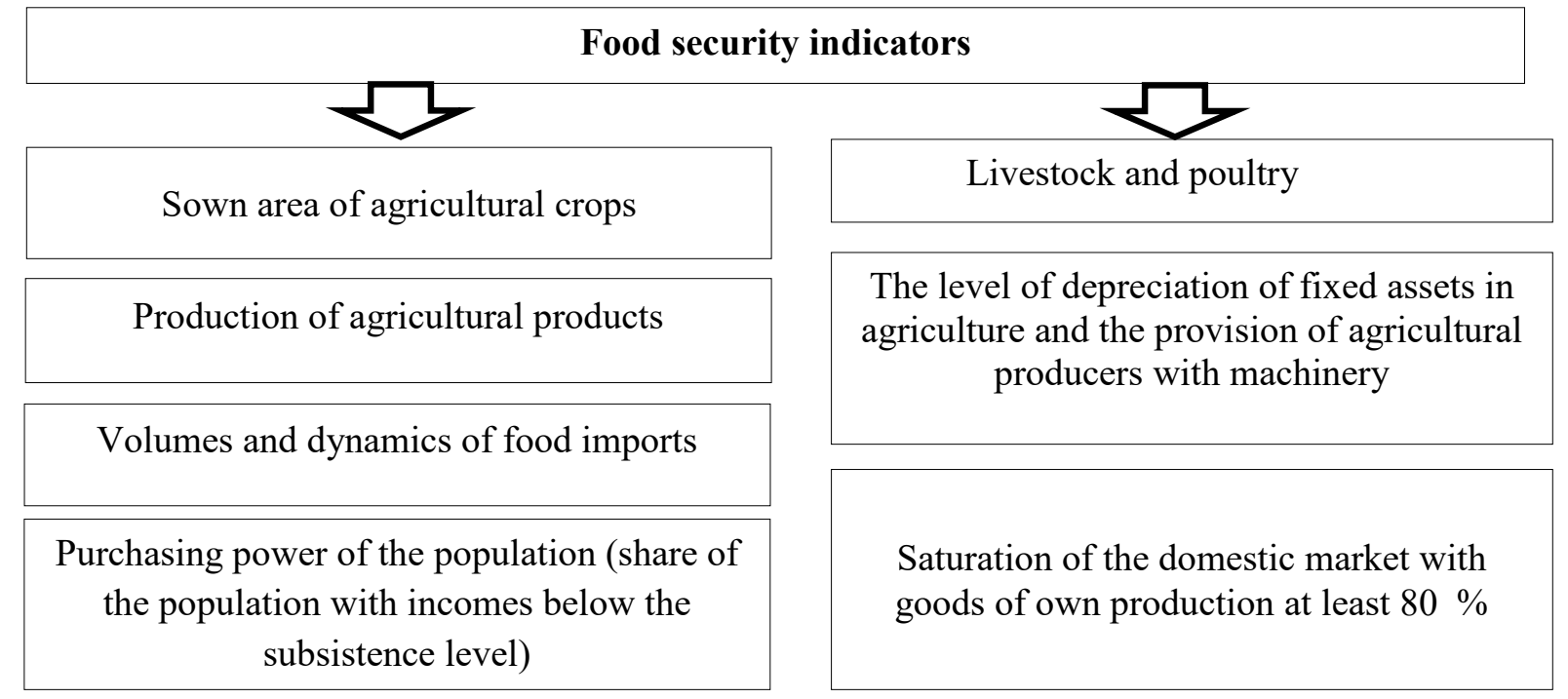

Fig. 1. Food security indicators 


\begin{tabular}{|c|c|c|c|c|}
\hline \multicolumn{5}{|c|}{$\begin{array}{r}\text { Table } 1 \\
\text { Main economic indicators of agricultural production in Kazakhstan }\end{array}$} \\
\hline Indicators & 2018 & 2019 & 2020 & $\begin{array}{l}\text { Growth } \\
\text { rate, \% }\end{array}$ \\
\hline $\begin{array}{l}\text { Gross output of agricultural products (services) at current } \\
\text { prices, million tenge }\end{array}$ & 4474088.1 & 5151163 & 6334668.8 & 141.5 \\
\hline Gross crop production, million tenge & 2411486.7 & 2817660.6 & 3687310.3 & 153 \\
\hline Gross livestock production million tenge & 2050455.8 & 2319496.7 & 2637460.7 & 128.6 \\
\hline $\begin{array}{l}\text { Index of physical volume of gross output (services) of } \\
\text { agriculture, as a percentage of the previous year }\end{array}$ & 103.5 & 99.9 & 105.7 & 102 \\
\hline Cultivated areas, thousand hectares, including & 15150 & 15396.6 & 15878.4 & 104.8 \\
\hline for grain crops & 11409.8 & 11413.9 & 12182.6 & 106.8 \\
\hline Productivity of grain and leguminous crops, c/ha & 13.5 & 11.4 & 12.8 & 95 \\
\hline Number of cattle, heads & 7150.9 & 7436.4 & 7850 & 109.7 \\
\hline Bird, million heads & 44.3 & 45 & 43.3 & 98 \\
\hline Pigs, heads, thousand heads & 815.1 & 798.7 & 813.3 & 99.7 \\
\hline Meat production in slaughter weight, thousand tons & 1059.4 & 1120.6 & 1168.6 & 110.3 \\
\hline Milk production, thousand tons & 5686.2 & 5864.9 & 6051.4 & 106.4 \\
\hline Labor productivity, thousand tenge per person & 2311.1 & 2466 & 2959.2 & 111 \\
\hline Profitability (loss) of agricultural production, total \% & 62.5 & 64.3 & 65.2 & 104.3 \\
\hline
\end{tabular}

However, despite the positive dynamics in the development of the industry until food security is fully ensured, the growth rate is insufficient, there are problems in the industry that may become threats to the country's food security in the future and today require their neutralization. These include:

- low share of agricultural products in the country's GDP $(5.1 \%$ in 2020) (despite the fact that Kazakhstan ranks second in the world in terms of arable land per capita, $43 \%$ of the country's population is rural);

- raw material orientation of exports of agricultural products and their low competitiveness;

- a fairly high share of food imports;

- insufficient level of veterinary and food safety;

- high level of wear of the main types of agricultural machinery;

- insufficient pace of renewal of agricultural machinery;

- saturation of the domestic market with nationally produced foodstuffs less than $80 \%$;

- insufficient efficiency of state regulation of the industry.

Today, about $70 \%$ of agricultural products produced in Kazakhstan are sold as raw materials, without processing, and finished products have a weak competitiveness. The share of food imports in domestic consumption remains very significant. Consider the general trend in the dynamics of imports and exports of agricultural products in Kazakhstan (Fig. 2).

The overall dynamics of exports and imports of agroindustrial products of Kazakhstan over the past three years has changed slightly, traditionally, exports of agro-industrial complex products are less than imports. The share of processed products in exports has increased over the past three years from $36.7 \%$ in 2018 to $39.9 \%$ in 2020 .

The normative level of food imports, according to international assessment standards, should be in the range from $18 \%$ to $35 \%$, which will not threaten the country's food security [5].
Kazakhstan in terms of total imports is within the standard $-11 \%$. If we consider imports by individual groups of goods, the situation is different: according to the Ministry of Agriculture, in 2019-2020, Kazakhstan imported about $40 \%$ of dairy, $29 \%$ of meat (the country buys abroad annually 150 thousand tons of chicken, 25 thousand tons of beef, 70 thousand tons of sausages) and about $43 \%$ - fruits and vegetables. However, positive developments can also be noted, for example, in 2020, the share of poultry meat imports decreased by $3.7 \%$ compared to 2018 and amounted to $45.3 \%$. This decrease is due to the start of operation of Makinskaya Poultry Farm LLP in the Akmola region, the productivity of which is 25 thousand tons of poultry meat per year and the expansion of the activities of the operating poultry farm of Aulie Ata Phoenix LLP in the Zhambyl region with a poultry meat productivity of up to 8,000 tons per year.

To date, the country is still dependent on imported products, which is a potential threat not only to food, but also to the economic security of the country. A positive moment is the increase in exports of agricultural products of Kazakhstan in 2020 by 174 million USD, while the volume of exports of processed agricultural products increased by $3.2 \%$ and amounted to 1.3 billion USD.

For the purpose of import substitution in Kazakhstan, programs for the development of dairy farming, poultry farming and pig breeding are being implemented. In 2020, investments in the amount of 559 billion tenge were attracted to the agro-industrial complex and 94 investment projects were launched. Promising investment projects include the construction of a meat processing plant with the participation of a large American multinational company in the field of meat processing "Tyson Foods Inc." and construction of a plant for the production of modern irrigation systems "Valmont Industries" (USA). For both projects, agreements were signed at the level of the Government of the Republic of Kazakhstan [6]. 


\section{Agrarian Bulletin of the Urals No. 01 (216), 2022}

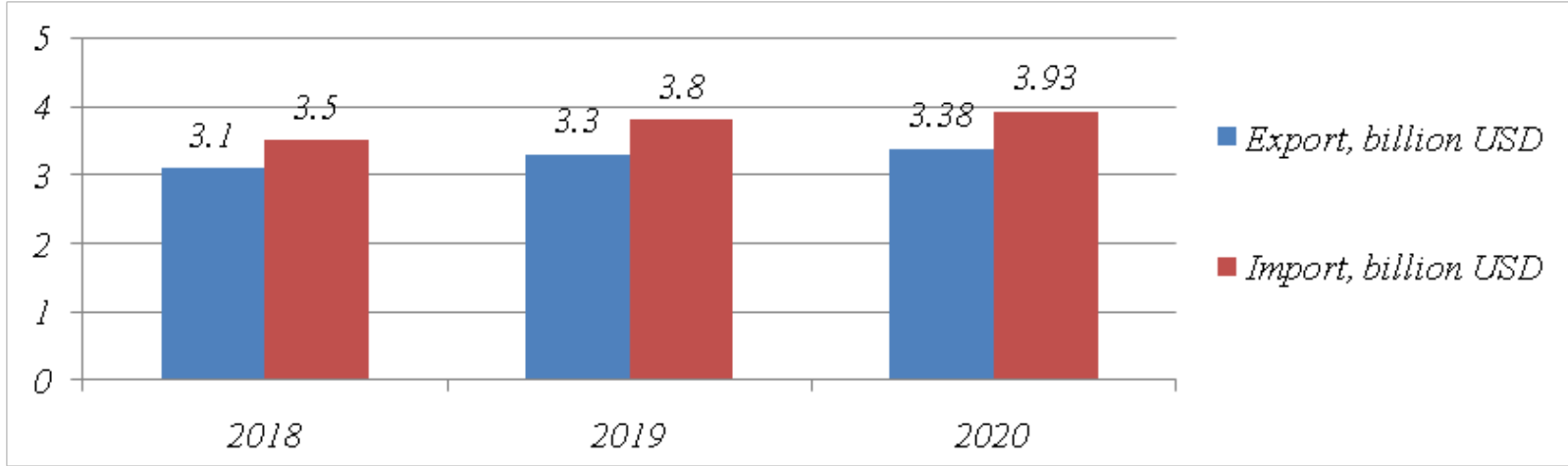

Fig. 2. Dynamics of import and export of agricultural products in Kazakhstan

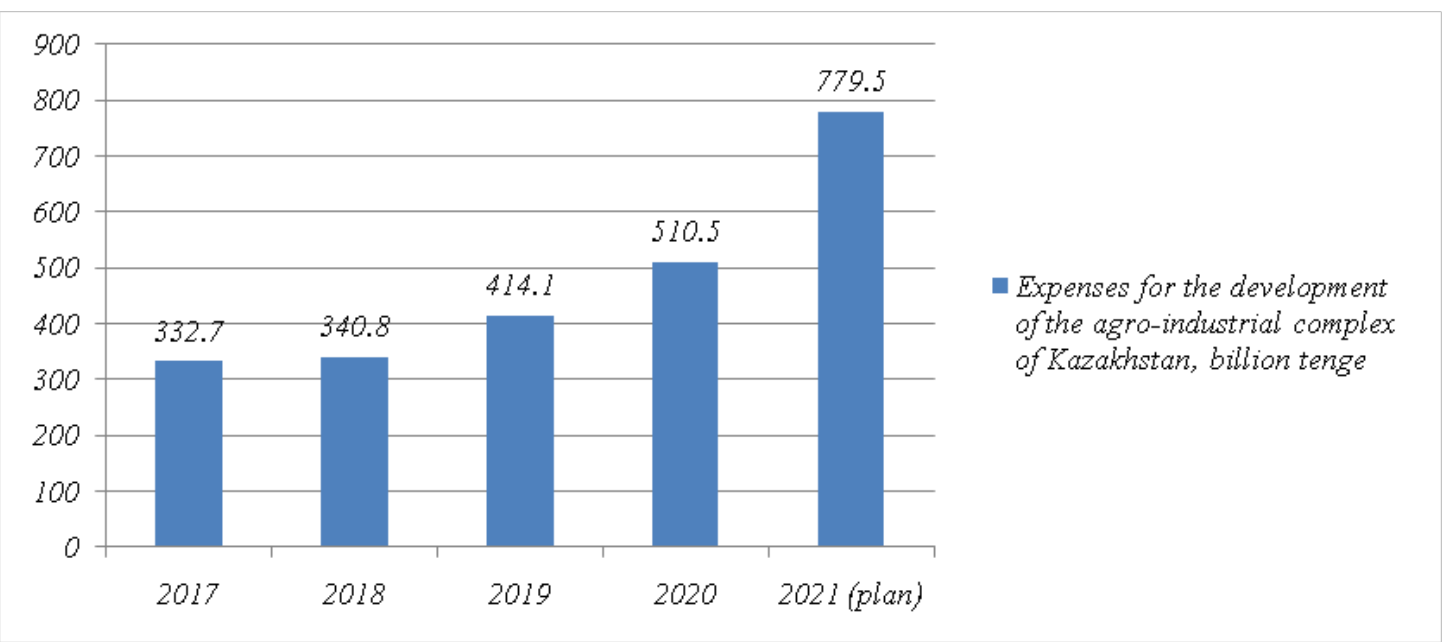

Fig. 3. Dynamics of public spending on the development of the agro-industrial complex of Kazakhstan

One of the most important indicators of food security is the level of depreciation of fixed assets in agriculture and the provision of agricultural producers with machinery. The average depreciation period of agricultural machinery is $10-12$ years; today, $80 \%$ of tractors, $51 \%$ of combines, $86 \%$ of seeders and $71 \%$ of reapers operate in the agricultural production of Kazakhstan with a service life of over 15 years. The average renewal rate for 20192020 reached $4 \%$ (3.5\% in 2018), with the required technological level from 10 to $12.5 \%$ per year and a minimum technological level of $6 \%$. Good rates of equipment renewal in Karaganda (4.6\%), Akmola (4.5\%), Zhambyl (4.4\%), East Kazakhstan and Aktobe (4.3\%) regions. Low rates of renewal are observed in Almaty and Turkestan regions $(2.8 \%$ and $1.8 \%)$ [7].

In 2020, the pace of renewal of the machine and tractor fleet was increased to $4.1 \%$. About 15.3 thousand units of agricultural machinery were purchased against 12 thousand units in 2019. The renewal of equipment was facilitated by subsidizing $25 \%$ of the cost of purchased agricultural equipment and reducing the cost of annual interest rates by $10 \%$ on loans and leasing, as well as the possibility of obtaining investment subsidies in advance to use them as a down payment for leasing equipment [8].

However, today in the agricultural sector of the country the volume of agricultural machinery that needs to be written off is very high and this slows down the pace of technical renewal of the industry. In order to increase labor productivity in agriculture, it is necessary to increase the pace of renewal of the machine and tractor fleet, the depreciation of which today is about $80 \%$, since the purchased new equipment is too small a share of the entire fleet.

It is impossible to solve the problems of further sustainable development of agricultural production, import substitution, increasing exports, updating the material and technical base of the country's agro-industrial complex without the support of the state and state regulation. State regulation is the economic impact of the state on the production, processing, sale of agricultural raw materials and agro-industrial products, on production and technical services and logistics of producers [9].

The implementation of state support for the agroindustrial complex of Kazakhstan is carried out through state programs for the development of the agro-industrial complex of the country. The total costs provided for in the republican and local budgets for the implementation of the "Program for the Development of the Agro-Industrial Complex of the Republic of Kazakhstan for 2017-2021" will amount to 2377.6 billion tenge at the end of 2021 (Fig. 3) [10].

The amounts are adjusted in accordance with the state budget for the corresponding financial year based on investment programs and programs for the development of the agro-industrial complex in the regions (5). In 2019, 324 billion tenge and in 2020, 394 billion tenge from government payments were subsidies or direct payments to agricultural producers [11]. 
In animal husbandry, subsidies are mainly aimed at further improvement of the insurance system in the agroreducing the cost of purchased breeding animals, the cost of conducting selection and breeding work, artificial insemination of farm animals, reducing the cost of production and processing of livestock products (meat, milk, wool).

In crop production, the cost of mineral fertilizers, herbicides, bioagents and biological products, seeds, fuels and lubricants and other inventory items is traditionally subsidized, as well as the production and processing of grain, beets, cotton, sunflower.

However, with ever-increasing state support for the industry, there is also a systematic underfunding of it, for example, in $2019,82 \%$ of the planned financial resources were allocated for the development of the industry (plan -507.6 billion tenge, actual -414.1 billion tenge), and in 2018 - only $75 \%$, in 2020 , out of the 745.6 billion tenge planned in the State Program, 510.5 billion tenge or $68 \%$ were actually allocated, 508.5 billion tenge were disbursed. Insufficient financing of the industry by the state directly affects the decrease in its efficiency and failure to achieve the main indicators of development and food security.

\section{Discussion and Conclusion}

Today, the country's agro-industrial policy is aimed at increasing the efficiency and competitiveness of domestic producers, reducing food dependence, reliable provision of the population of the republic with agricultural products and improving the quality of products [12].

In order to further sustainable development of the agro-industrial complex and ensure the country's food security, the Ministry of Agriculture of Kazakhstan developed the "Concept for the development of the agroindustrial complex of Kazakhstan for 2021-2030" and the "National project for the development of the agroindustrial complex for 2021-2025". The concept defines the priorities and vectors for the development of the industry for the long term, therefore, it includes systemic measures, including changes in legislation and the regulatory framework. The national project is focused on solving specific tasks and projects that require concentration of efforts and resources [15].

To further ensure the country's food security and improve the efficiency of agricultural production, it is proposed to introduce the following measures:

1. Increasing the effectiveness of state support measures, taking into account the phased introduction of counter obligations for business, regulatory consolidation and specialization of regions. Regulatory consolidation will allow farmers to plan their activities for the long term and ensure the stability of development. Preliminary assessment of the specialization of the region, its natural and climatic conditions, socio-economic level of development will make it possible to more effectively implement state policy.

2. Expansion of lending channels and financing instruments for the subjects of the agro-industrial complex, (t) Law of the Republic of Kazakhstan "On State Regulation of the Development of the Agro-Industrial Complex and Rural Territories" have come into force, providing for the introduction of a new system of voluntary insurance in the agro-industrial complex and the loss of the Law of the Republic of Kazakhstan "On Compulsory Insurance in Crop Production". The new system provides state support in the form of subsidizing insurance premiums in the amount of $50 \%$. In 2022, it is planned to increase the financing of the program for subsidizing interest rates when lending to subjects of the agro-industrial complex by second-tier banks. The subsidizing of interest rates for the purchase of agricultural machinery, technological equipment and farm animals on lease will also continue. It is planned to introduce a program of investment subsidies, which provides for the reimbursement of expenses for investment investments of agricultural producers in the amount of $25 \%$. It is planned to further promote and introduce a new mechanism for guaranteeing loans from second-tier banks for subjects of the agro-industrial complex. The guarantor under this program will be the Fund for Financial Support of Agriculture JSC. The new guarantee mechanism will help commercial banks reduce credit risks when issuing agricultural loans and make the agricultural sector more attractive for banks in terms of financing. First of all, the guarantee will be issued for the implementation of investment projects in agriculture, which require medium-term and long-term credit resources, in case of insufficient collateral. The guarantee fee is $30 \%$ of the amount of the guarantee, of which $29.9 \%$ is paid by the local executive body, $0.1 \%$ is paid by the subject of the agro-industrial complex.

3 . Saturation of the domestic market with socially significant food products at the level of $80 \%$, through the implementation of investment projects for import substitution, increasing the share of local content in public procurement, strengthening quality control and safety of goods. By 2025, it is planned to put into operation 845 investment projects worth 4,560 billion tenge in the republic, which will increase the volume of agricultural production. The Ministry of Agriculture oversees the implementation of these investment projects at all stages of their life cycle: this is how the main investors of projects in the regions are identified, the projects are agreed with the leaders of the regions, included in the Roadmaps, and the relevant agreements are signed.

4. Increasing the export of processed agricultural products by 2 times (from 1.1 in 2020 to 2.2 billion USD in 2025), through the implementation of export-oriented investment projects, improving cross-border logistics in key export directions, removing barriers and facilitating exports. For exhibition-oriented investment projects, state support is provided for providing concessional loans, subsidies, land resources, infrastructure. 
1. Shagayda N. I., Uzun V. Ya. Prodovol'stvennaya bezopasnost'v Rossii: monitoring, tendentsii i ugrozy [Food Security in Russia: Monitoring, Trends and Threats] // Voprosy Ekonomiki. 2015. No. 5. Pp. 63-78. (In Russian.)

2. Informatsionno-analiticheskiy obzor k parlamentskim slushaniyam na temu "Voprosy razvitiya agropromyshlennogo kompleksa" [Information and analytical review for the parliamentary hearings on the topic "Issues of the development of the agroindustrial complex"]. Nur-Sultan: Apparat senata. Informatsionno-analiticheskiy otdel, 2020. 55 p. (In Russian.)

3. Goncharenko L. P., Akulina F. Ekonomicheskaya bezopasnost': uchebnik dlya vuzov [Economic Security: textbook for universities]. Moscow: Yurayt, 2020. 478 p. (In Russian.)

4. Dokholyan S. V., Vartanova M. L. Strategiya razvitiya agrarnoy sfery strany v usloviyakh zameshcheniya importa tovarami otechestvennogo proizvodstva - osnova prodovol'stvennoy bezopasnosti [Strategy for the development of the country's agrarian sphere in the conditions of replacing imports of domestic goods - the basis of food security] // Rossijskoe predprinimatel'stvo. 2017. Vol. 18. No. 12. Pp. 1877-1904. (In Russian.)

5. Nurbekova Sh. K., Akhmedieva M. A. Prodovol'stvennaya bezopasnost' Kazakhstana - Mezhdunarodnyy ekonomicheskiy forum [Food Security of Kazakhstan - International Economic Forum] [e-resource]. URL: https://be5. biz/ekonomika1/r2013/4319.htm (date of reference: 10.11.2021). (In Russian.)

6. Razvitie sel'skogo khozyaystva Kazakhstana [Development of agriculture of Kazakhstan] [e-resource]. URL: https:// businessmir.kz/2020/03/05/razvitie-selskogo-hozyajstva-kazahstana (date of reference: 11.11.2021). (In Russian.)

7. Kekchebaev E., Zhakupova G. Marketingovye issledovaniya sel'skogo khozyaystva Kazakhstana - Ekonomika Kazakhstana [Marketing research of agriculture of Kazakhstan - Economics of Kazakhstan] [e-resource]. URL: https://marketingcenter.kz/20/rynok-selskoe-khoziaistvo-kazakhstan.html\#skhapk (date of reference: 11.11.2021). (In Russian.)

8. Otchet ministra sel'skogo khozyaystva Respubliki Kazakhstan Omarova S. K. pered naseleniem [Report of the Minister of Agriculture of the Republic of Kazakhstan Omarov S. K. before the population] [e-resource]. URL: https://www.gov.kz/memleket/entities/moa/press/article/details/34455 (date of reference: 12.11.2021). (In Russian.) 9. Itogi 2020 goda: kakaya gospodderzhka byla okazana APK Kazakhstana [Results of 2020: What kind of state support was provided by the APC of Kazakhstan] [e-resource]. URL: https://www.inform.kz/ru/itogi-2020-goda-kakayagospodderzhka-byla-okazana-apk-kazahstana_a3738388 (date of reference: 13.11.2021). (In Russian.)

10. Dyuzelbayeva G., Malyarenko O. The role of state regulation in the development of the agro-industrial complex of the region (Kostanay region) // Agrarian Bulletin of the Urals. 2020. No. 02 (193). Pp. 70-77.

11. "Gosudarstvennaya programma razvitiya agropromyshlennogo kompleksa RK na 2017-2021 gody" ["The state program for the development of the agro-industrial complex of the Republic of Kazakhstan for 2017-2021"] [e-resource]. URL: http://mgov.kz (date of reference: 13.11.2021). (In Russian.)

12. Prilozheniya k Natsional'nomu proektu po razvitiyu agropromyshlennogo kompleksa Respubliki Kazakhstan na 2021-2025 gody [Annexes to the national project on the development of the agro-industrial complex of the Republic of Kazakhstan at 2021-2025] [e-resource]. URL: https://admin.primeminister.kz/assets/media/prilozhenie-k-natsproekt-apk.pdf (date of reference: 13.01.2021). (In Russian.)

13. Statisticheskie dannye Komiteta po statistike MNE RK [Statistical data of the Statistical Statistics of the MAN RK] [e-resource]. URL: http://stat.gov.kz/faces/homePage (date of reference: 15.11.2020). (In Russian.)

14. Chupina I. P., Mokronosov A. G. Sistemnyy kharakter prodovol'stvennoy bezopasnosti Rossii [The systemic nature of food security in Russia] // Agrarian Bulletin of the Urals. 2016. No. 05 (147). Pp. 118-122. (In Russian.)

15. Doklad ministra sel'skogo khozyaystva Respubliki Kazakhstan Omarova S. K. "O razvitii APK Kazakhstana na 2021-2025 gg." [Report of the Minister of Agriculture of the Republic of Kazakhstan Omarova S. K. "On the development of APK in Kazakhstan at 202-2025"] [e-resource]. URL: https:/www.gov.kz/memleket/entities/moa/press/ article/details/34455 (date of reference: 15.11.2021). (In Russian.)

16. Kopteva L., Romanova I., Kulakova S. V. Problems of meat market in terms of ensuring world's food security // XIII International Scientific and Practical Conference "State and Prospects for the Development of Agribusiness INTERAGROMASH 2020". Rostov-on-Don, 2020. Article number 13039.

17. Silaeva L. P., Kul'chikova Zh.T., Barinova E. V. Innovative Development of the Meat Sub-sector Based on the Rational Allocation of Production // Complex Systems Innovation and Sustainability in the Digital Age. 2020. Vol. 1. Pp. 315-324.

\section{Authors'information:}

Olga I. Malyarenko', candidate of economic sciences, associate professor, ORCID 0000-0002-8272-148X; +7 705 561-92-84, Malyarenko_Olga@mail.ru

Gulnara M. Kushebina ${ }^{2}$, candidate of economic sciences, associate professor, ORCID 0000-0002-7782-8469; +7701343-33-04,duz_77@mail.ru

${ }^{1}$ Kostanay Branch of Chelyabinsk State University, Kostanay, Republic of Kazakhstan

${ }^{2}$ Kostanay Engineering and Economic University named after. M. Dulatov, Kostanay, Republic of Kazakhstan 